\title{
Malignant Supraglottis Neoplasm
}

National Cancer Institute

\section{Source}

National Cancer Institute. Malignant Supraglottis Neoplasm. NCI Thesaurus. Code C3545.

A malignant neoplasm that affects the suprag lottic area of the larynx. The vast majority of cases are squamous cell carcinomas. 